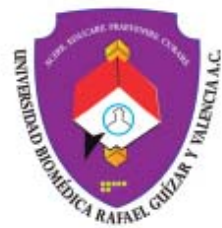

Vol. 8, Núm. 2

Julio-Diciembre 2021. pp. 99-101

doi: $10.35366 / 103089$

Cultural

\title{
La cosmovisión de la muerte en los Náhuatl de la Huasteca. Xantolo
}

\author{
The cosmovision of death in the Nahuatl of the Huasteca. \\ Xantolo
}

Jazmín del Carmen Luna Contla, ${ }^{*}$ Miguel Ángel Jiménez Ortíz, ${ }^{\ddagger}$ Gerardo José Roberto Ortega Matías, ${ }^{\S}$ María del Rocío Durán López," Daniel Sánchez Ruiz"

\section{RESUMEN}

El Día de Muertos es una fiesta que mezcla tradiciones y creencias de las culturas prehispánicas y españolas traídas durante la Colonia. El Xantolo representa la unión sagrada entre los vivos y muertos, pues, de acuerdo con las creencias de quienes habitan en la Huasteca, la noche del $1^{\circ}$ de noviembre las almas de los difuntos regresan para convivir con sus seres queridos.

Palabras clave: Día de Muertos, zona Huasteca, Xantolo, México.

\section{ABSTRACT}

The Day of the Dead is a festival that mixes traditions and beliefs of the pre-Hispanic and Spanish cultures brought during the Colony. The Xantolo represents the sacred union between the living and the dead because, according to the beliefs of those who inhabit the Huasteca, on the night of November 1, the souls of the deceased return to live with their loved ones.

Keywords: Day of the dead, Huasteca zone, Xantolo, Mexico.

\section{INTRODUCCIÓN}

La Huasteca es una región de México que se caracteriza por selvas frondosas, ríos de color turquesa, espectaculares cascadas e inmensos abismos. Los nativos del lugar
Ilaman al Día de los Fieles Difuntos o Día de Muertos, la fiesta de Xantolo.

Xantolo (se pronuncia chantolo) es un vocablo que viene del término castellano xanto (santo) y del náhuatl olo (abundancia), y que significa todos santos (Figura 1).

\footnotetext{
* Coordinador Terapia Física y Rehabilitación.

${ }^{\ddagger}$ Coordinador Psicología.

Coordinador Optometría y Rehabilitación Visual.

" Coordinador Enfermería.

"Coordinador Nutrición.

Correspondencia:

Jazmín del C. Luna Contla

E-mail: rehabilitacion@universidadbrgyv.com

Recibido: 20-08-2021. Aceptado: 04-11-2021.
}

Citar como: Luna CJC, Jiménez OMA, Ortega MGJR, Durán LMR, Sánchez RD. La cosmovisión de la muerte en los Náhuatl de la Huasteca. Xantolo. Plast Restaur Neurol. 2021;8 (2): 99-101. https://dx.doi.org/10.35366/103089 


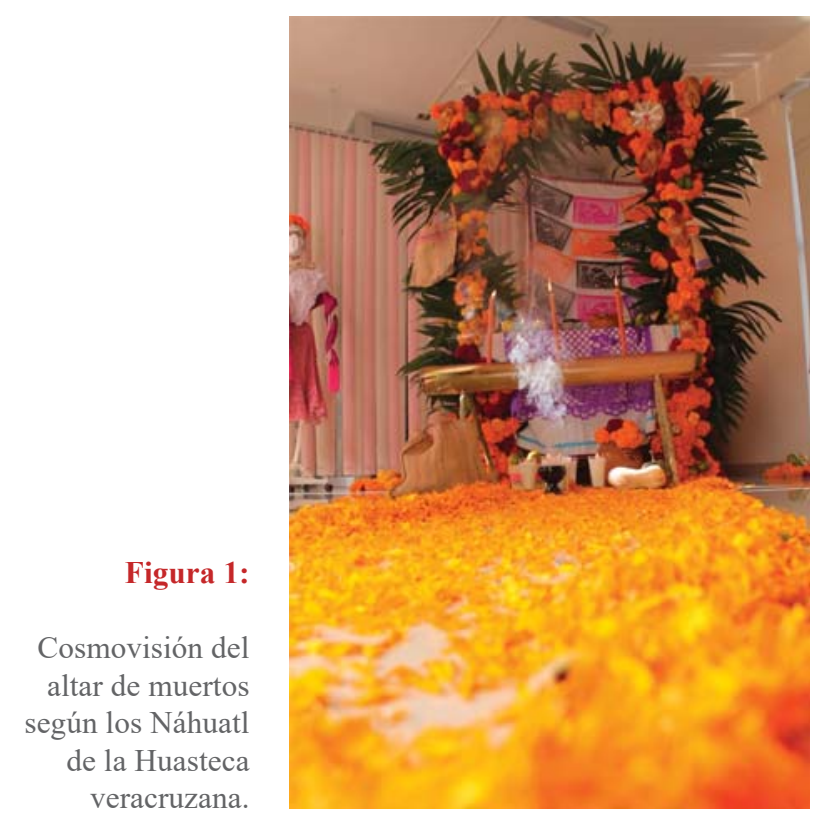

Es una celebración que involucra diferentes tipos de ofrendas, desfiles, bailes tradicionales y gastronomía, los habitantes de la Huasteca creen que el 01 y 02 de noviembre, vivos y muertos conviven en la tierra y se puede pedir a los espíritus por sus cosechas y agradecer todo lo bueno que recibieron a lo largo del año con bailes, altares, ofrendas y comida dedicados solamente a ellos. ${ }^{1}$

Las calles se adornan con grandes arcos decorados con flores de cempasúchil -características por su olor y color naranja-, papeles picados de colores y luces.

El Día de Muertos es una fiesta que mezcla tradiciones y creencias de las culturas prehispánicas y españolas traídas durante la Colonia. El Xantolo representa la unión sagrada entre los vivos y muertos, pues, de acuerdo con las creencias de quienes habitan en la Huasteca, la noche del $1^{\circ}$ de noviembre las almas de los difuntos regresan para convivir con sus seres queridos. $^{2}$

\section{DESARROLLO}

La Huasteca es el nombre de una región mexicana que comprende el norte del estado de Veracruz, el sur de Tamaulipas, y partes de los estados de San Luis Potosí, Puebla, Hidalgo y la Sierra Gorda en Querétaro. Por esta razón, se conoce también con el nombre de Huasteca potosina, poblana, hidalguense, tamaulipeca y veracruzana. En este documento cultural nos concentramos en la Huasteca veracruzana. Si bien el Xantolo se celebra en toda la región, podemos decir que su epicentro es en el municipio de Tempoal (Veracruz), en una celebración que comienza el 31 de octubre y se extiende hasta el 03 de noviembre (Figura 2).

El Xantolo es una de las fiestas más importantes dentro de la veintena de comunidades indígenas en la Huasteca Veracruzana que celebran Xantolo, hay dos grupos: náhuatl y teenek. Existen algunas diferencias entre los festejos de ambos grupos, pero hay dos cosas que no faltan en ninguna localidad: las ofrendas y las danzas de los huehues (o ancestros).

En cada hogar se instala el altar de muertos, que consta de dos arcos de ramas del árbol llamado guácima o cualquier otra vara flexible. Se le adorna con flores de cempasúchil y mano de león y se le cubre con todo aquello que le gustaba al difunto.

Las comunidades náhuatl montan su ofrenda en mesas y los teenek lo hacen en el piso para estar en contacto con la tierra; en la ofrenda hay fruta, pan de muerto y flores, incluyen platillos típicos como el bolín (un tamal para 10 personas) y atole de tamarindo, guayaba o mandarina.

En la parte superior de las ofrendas suele agregarse un arco de palma con flores de cempasúchil, el cual representa la puerta del cielo. Se adorna con papel picado de colores y se colocan imágenes religiosas. Tampoco faltan el copal o el incienso (Figuras 2 y 3 ).

Desde el 31 de octubre se instalan los altares, y en muchas ocasiones son trasladados desde las casas hacia los cementerios.

El día primero de noviembre es destinado a los infantes fallecidos y por ello la ofrenda cuenta con dulces, refrescos, piñatas, juguetes y todo lo que disfrutaban los pequeños en vida.

El día dos es de los difuntos mayores y el altar se llena de colorido, olores y sabores diversos que van desde

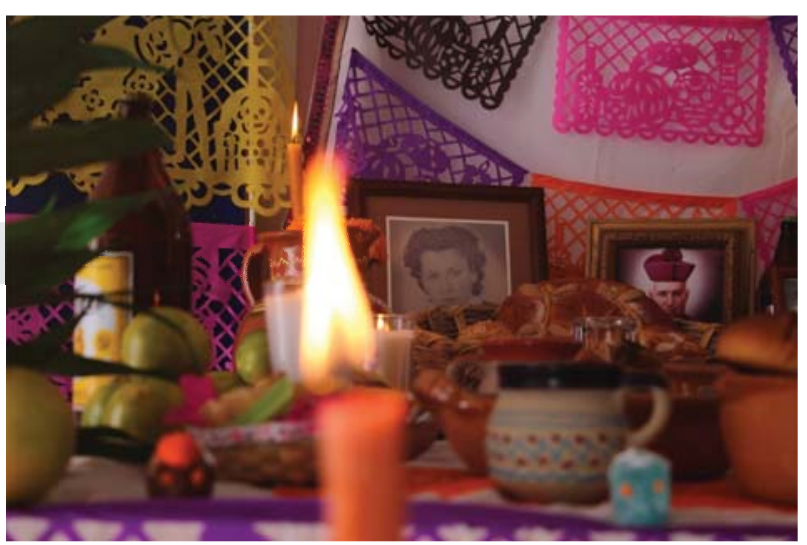

Figura 2: Las almas de los fieles difuntos se acercan a la luz de la convivencia terrenal. 
platillos como el mole o los tamales, dulce de calabaza, tequila y cerveza, así como chocolate y pan de muerto. La Huasteca guarda recetas singulares para estos días. ${ }^{3}$

\section{DISCUSIÓN}

Como te adelantábamos unos párrafos arriba, las danzas son otro elemento esencial en el Xantolo. Los difuntos se reciben con música y baile en comparsas que, desde el 30 de octubre, recorren las calles de cada pueblo hasta llegar a las plazas principales. Uno de los eventos más esperados del Xantolo es la representación con los habitantes de la comunidad disfrazados de ancianos con máscaras artesanales, talladas en madera y atuendos de estilo vaquero. En Tempoal se conoce este evento como «La Viejada». La danza, bailada al ritmo de sones y huapangos, simboliza la materialización de las almas de los muertos, que vienen a celebrar y a disfrutar de la comida que se les ofrenda. Sin embargo, detrás de ellos viene la Muerte, siguiéndolos para llevarlos de regreso. Por ello se esconden en el cuerpo de los vivos, quienes deben ponerse máscaras para no ser reconocidos por ésta. En el Xantolo no puede faltar el Diablo, que viene a hacer sus travesuras... (Figura 4).

Participan cientos de locales, quienes bailan al son del violín, la jarana y la guitarra. Todos Ilevan máscaras de madera que representan diversos personajes, como el viejo, la muerte, diferentes animales o hasta diablos. Las fiestas de Xantolo terminan el 03 de noviembre, cuando

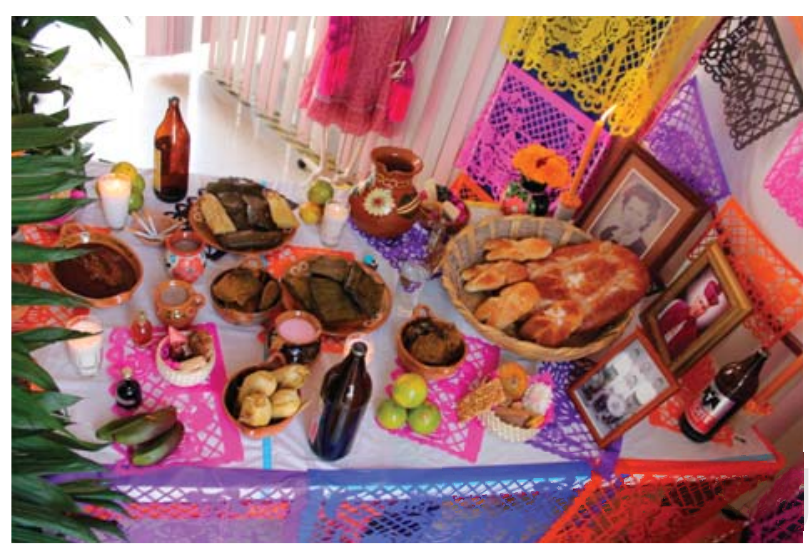

Figura 3: Los alimentos de preferencia de los finados se colocan en un altar esperando su llegada.

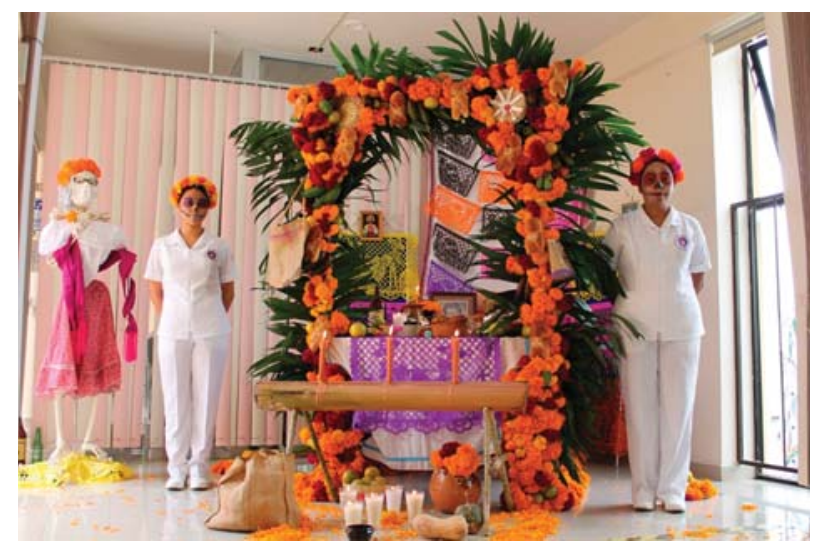

Figura 4: Las catrinas hacen su aparición dentro de la alegoría del arco de flores de cempasúchil y la luz que las guía al mundo de los vivos.

se hace la Fiesta del Destape, una tradición en la que las cuadrillas bailan de nuevo toda la noche y donde al final descubren sus caras y se conoce a la persona que portó ese disfraz.

Para hablar de la Huasteca hay que haber nacido allá. Saborear la carne seca, con traguitos de mezcal. Fumar cigarrito de hoja, prenderlo con pedernal...

\section{REFERENCIAS}

1. Pérez LI. Para hablar de la Huasteca. Una historia referenciada desde la huasteca serrana de Veracruz. Editorial: Instituto Veracruzano de la cultura. México, 2018.

2. González TY. Cosmovisión Náhuatl Prehispánica. En D.S. coordinación, primer encuentro Náhuatl: Los nahuas de hoy. México: INAH. pp. 37-43.

3. Sandstrom AR. El maíz es nuestra sangre. Cultura e identidad étnica en un pueblo indio azteca contemporáneo. México 2010. CIESAS.

Declaración de ética: Se cumplieron los requerimientos éticos.

Financiamiento: Este estudio no fue apoyado por subvenciones.

Conflicto de intereses: Los autores declaran que la investigación se llevó a cabo en ausencia de relaciones comerciales o financieras que pudieran interpretarse como un posible conflicto de intereses. 